\title{
EFFECTS OF PENTOBARBITAL AND MEPERIDINE ON CANINE CEREBRAL AND TOTAL OXYGEN CONSUMPTION RATES*
}

\author{
Joseph M. Messick, Jr., M.D., ANd Richard A. Theye, M.D. $†$
}

Clinical studies have not always supported Guedel's belief that preanaesthetic medication with hypnotics and narcotics lowers the metabolic rate.$^{1,2}$ Only small, insignificant effects on the total-body oxygen consumption rate $\left(\dot{\mathrm{V}}_{2}\right)$ occur in man with meperidine (100 mg intravenously), ${ }^{3}$ pentobarbital $(1.5 \mathrm{mg} / \mathrm{kg}$ intramuscularly), ${ }^{4}$ or morphine ( $10 \mathrm{mg}$ intramuscularly)..$^{5} \mathrm{~A}$ decrease of 11 per cent in $\dot{V}_{O_{2}}$ has been observed, however, with the combination of pentobarbital (100 mg orally) and meperidine (50 to $100 \mathrm{mg}$ intramuscularly). ${ }^{6}$ Furthermore, during halothane anaesthesia, $\dot{V}_{2}$ was 12 per cent lower in patients premedicated with the pentobarbital-meperidine combination than in those who were not. ${ }^{7}$ These inconsistencies have led to the present studies wherein the individual effects of pentobarbital and meperidine on both total $\dot{V}_{o_{2}}$ and cerebral oxygen consumption rate $\left(\mathrm{CMRo}_{2}\right)$ have been determined in dogs during halothane anaesthesia.

\section{MerHods}

Four groups of unpremedicated dogs (11 to $21 \mathrm{~kg}$ ) were studied during anaesthesia with 1 per cent halothane intravenously) and intubation with a cuffed endotracheal tube, ventilation was maintained with a Harvard pump. Cannulae were placed in a femoral artery and vein for pressure measurements, sampling, and intravenous infusion of fluids and medications. Catheters were passed (via the external jugular vein) to the right atrium and the pulmonary artery, and positioned by means of pressure patterns. A thermistor was passed to the right atrium. The dog was clipped and placed prone in a water bath with head and neck supported above water. Adjustments were made as required to provide a right atrial ( $\dot{\mathrm{Vo}}_{2}$ studies) or epidural $\left(\mathrm{CMRo}_{2}\right.$ studies) temperature of $37.0^{\circ} \mathrm{C}$; an arterial $\mathrm{PCO}_{2}\left(\mathrm{~Pa}_{\mathrm{C}^{\circ} \mathrm{O}_{2}}\right)$ of 34 to $45 \mathrm{~mm} \mathrm{Hg}$ (I-L electrodes at $37.0^{\circ} \mathrm{C}$ ); an end-expired halothane concentration $\left(\mathrm{H}_{\text {exp }}\right)$ of 0.8 to 0.9 per cent (Liston-Becker infrared analyser); and continuous muscle relaxation (succinyldicholine, $150 \mathrm{mg} / \mathrm{hr}$, intravenously). Blood loss was replaced in equal volumes.

The total-body oxygen consumption rate was measured by means of a closedcircuit spirometry system described previously. ${ }^{8}$ The oxygen content of arterial and mixed venous blood was determined by an oxygen electrode method. ${ }^{9}$

'Presented at the Annual Meeting of the Canadian Anaesthetists' Society, June 16-19, 1969. This investigation was supported in part by Special Research Fellowship 1-F3-GM-37, 307-01 from the National Institute of General Medical Sciences (USA), and by Research Grants HE-4881 and NB-7507 from the National Heart Institute, Public Health Service (USA).

$\dagger$ Mayo Clinic and Mayo Foundation: Section of Anesthesiology, Rochester, Minnesota.

\$Provided by Ayerst Laboratories, New York. 
Cardiac output ( $\dot{Q}$ ) was calculated (Fick principle) from $\dot{V}_{o_{2}}$ and the difference between arterial and mixed-venous oxygen content. After control determinations, pentobarbital ( $2 \mathrm{mg} / \mathrm{kg}$ ) or meperidine ( 1 to $10 \mathrm{mg} / \mathrm{kg}$ ) was diluted to $10 \mathrm{ml}$ and injected intravenously $(1 \mathrm{ml} / \mathrm{min}) . \mathrm{V}_{2}$ was measured for the next one to four hours. The positions of the catheters and thermistor were confirmed at autopsy.

The cerebral oxygen consumption rate was determined using a brain preparation described previously ${ }^{10}$ and later modified. ${ }^{11}$ Cannulation of the superior sagittal sinus provided for direct measurement of cerebral blood flow (CBF, $\mathrm{ml} / \mathrm{min}$ ) from the anterior, superior, and lateral portions of the cerebral hemispheres. The oxygen content of arterial and sagittal-sinus blood was determined by the previously mentioned oxygen electrode method. The $\mathrm{Po}_{2}$ of sagittal-sinus blood $\left(\mathrm{Pss}_{\mathrm{O}_{2}}\right)$ was determined by electrodes at $37^{\circ} \mathrm{C}$. $\mathrm{CMRo}_{2}(\mathrm{ml} \mathrm{O} / \mathrm{min})$ was calculated from $\mathrm{CBF}$ and the difference in arterial and sagittal-sinus oxygen content (Fick principle). After control determinations, pentobarbital ( $2 \mathrm{mg} / \mathrm{kg}$ ) or meperidine $(2 \mathrm{mg} / \mathrm{kg}$ ), diluted to $10 \mathrm{ml}$ total volume, was injected through the femoral vein cannula $\left(1 \mathrm{ml} / \mathrm{min}\right.$ ), and $\mathrm{CMRo}_{2}$ was measured for one to three hours. At the conclusion of each experiment, blue vinyl acetate was injected through the indwelling sagittal-sinus catheter, the brain was removed and weighed, and the absence of extracerebral vascular communications was confirmed. $\mathrm{CMRo}_{2}(\mathrm{ml} \mathrm{O} 2 / \mathrm{min} / 100 \mathrm{gm}$ brain) was calculated on the assumption that the collection system receives the blood from 43 per cent of the total brain, a factor previously established in other studies. ${ }^{10}$ In one dog not given either pentobarbital or meperidine, no significant change in $\mathrm{CMRo}_{2}$ (range $\pm 5 \%$ ) occurred during a four-hour period.

\section{Results}

After pentobarbital, $\dot{\mathrm{V}} \mathrm{O}_{2}$ decreased in all dogs (Fig. 1), and the mean decrease of 7 per cent was significant (Table I). No significant change occurred in $\dot{Q}$, mean arterial pressure (MAP) (Table I), $\mathrm{Pa}_{\mathrm{O}_{2}}, \mathrm{~Pa}_{\mathrm{CO}_{2}}$, right atrial temperature (TA), or $\mathrm{H}_{\exp }$ (Table II). Meperidine did not produce any change in $\mathrm{Vo}_{2}$ over a dose range of tenfold (Fig. 2, Table I). Although the decrease of 17 per cent in MAP was significant (Table I), no significant changes occurred in $\dot{Q}$ (Table I), $\mathrm{Pa}_{\mathrm{O}_{2}}, \mathrm{~Pa}_{\mathrm{CO}_{2}}, \mathrm{~T}_{\mathrm{A}}$, or $\mathrm{H}_{\text {exp }}$ (Table II).

With pentobarbital, $\mathrm{CMRo}_{2}$ decreased in six of the seven dogs (Fig. 3), and the mean decrease of 10 per cent was significant (Table III). Although the reduction of 24 per cent in CBF was significant (Table III), it occurred in the absence of significant changes in the other variables monitored (Tables III and IV), and in the presence of a $\mathrm{Pss}_{\mathrm{O}_{2}}$ that was always greater than $27 \mathrm{~mm} \mathrm{Hg}$. This is well above the value of 19 to $20 \mathrm{~mm} \mathrm{Hg}$ suggested by Alexander and associates ${ }^{12}$ to be the cerebral venous $\mathrm{Po}_{2}$ below which anaerobic cerebral metabolism may occur. Meperidine resulted in a decrease of $\mathrm{CMRo}_{2}$ in each dog (Fig. 4), and the mean decrease of 13 per cent was significant (Table III). No significant changes occurred in $\mathrm{Pa}_{\mathrm{CO}_{2}}$, epidural temperature (TE), MAP, $\mathrm{PsS}_{\mathrm{O}_{2}}$, or $\mathrm{H}_{\text {exp. }}$. The lowest $\mathrm{Pss}_{\mathrm{O}_{2}}$ was $33 \mathrm{~mm} \mathrm{Hg}$. 


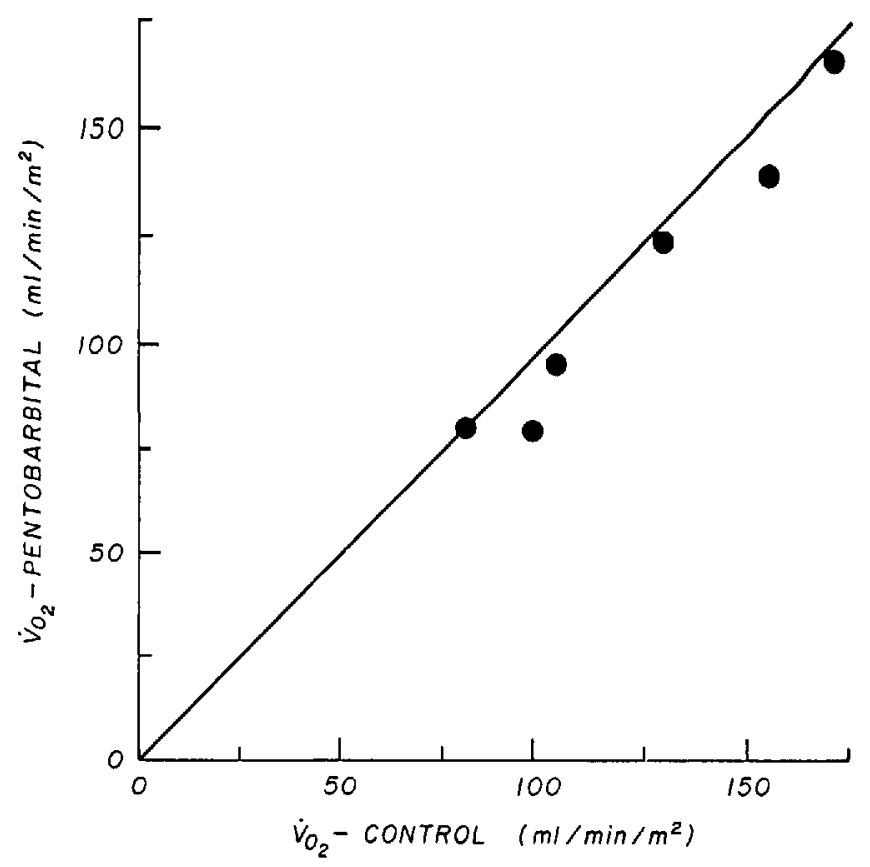

Figure 1. $\dot{\mathrm{V}} \mathrm{O}_{2}$ before and after pentobarbital $2 \mathrm{mg} / \mathrm{kg}$ in each of six dogs. Solid diagonal line is line of identity.

Control values in both the $\dot{\mathrm{Vo}}_{2}$ and $\mathrm{CMRo}_{2}$ studies were similar to those in previous studies using these methods $\left(124 \mathrm{ml} / \mathrm{min} / \mathrm{m}^{2}\right.$ and 4.5 to $4.7 \mathrm{ml} / \mathrm{min} / 100$ gm for $\dot{\mathrm{V}}_{2}$ and $\mathrm{CMRo}_{2}$, respectively). ${ }^{11,13,14}$

\section{Discussion}

These results with pentobarbital and meperidine are compatible with previous findings in man after these drugs were used alone $e^{3,4,15}$ or in combination, ${ }^{6,7}$ and they support Guedel's original belief that hypnotics and narcotics lower the metabolic rate. ${ }^{1}$ Extrapolation $\left.t\right)$ man of the results of the present studies is limited, however, not only by known species-related differences but also by actual differences in absolute values for $\mathrm{VO}_{2}$ and $\mathrm{CMRo}_{2}$ and the relationships between brain mass and body surface area, and by the use of general anaesthesia in the present studies. Dogs are known to metabolize pentobarbital and meperidine approximately four times faster than humans, ${ }^{16,17}$ and thus would necessarily have different blood levels of the drugs and different rates of change of these levels than would man after equivalent doses. The changes in $\mathrm{CMRO}_{2}$ in the present studies reflect primarily altered cortical tissue metabolism. ${ }^{10}$ Because cortical tissue is believed to have a higher metabolic rate than other brain tissue, ${ }^{18}$ application of $\mathrm{CMRO}_{2}$ changes in cortical tissue to the brain as a whole is likely to result in falsely high values. Also, whereas total $\mathrm{CMRo}_{2}$ of the dog is less than 5 per cent of the total $\dot{\mathrm{V}}_{2}$, the total $\mathrm{CMRo}_{2}$ of adult man is approximately 20 per cent of the total $\dot{\mathrm{V}}_{2}$. 


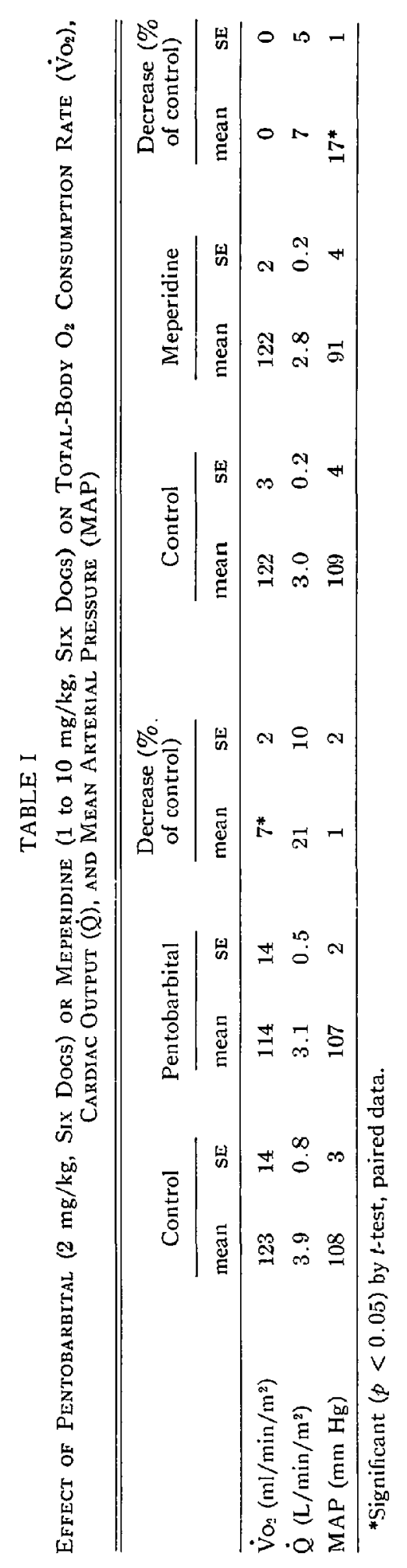


MESSICK \& THEYE: EFFECTS OF PENTOBARBITAL AND MEPERIDINE

TABLF. II

$\mathrm{Pa}_{2}, \mathrm{PaCO}_{2}$, Right Atrial Temperature (TA), and

End-Expired Halothane Concentration $\left(\mathrm{H}_{\text {exp }}\right)$ in $\dot{V}_{2}$ Studies

\begin{tabular}{|c|c|c|c|c|c|c|c|c|}
\hline & \multicolumn{2}{|c|}{ Control } & \multicolumn{2}{|c|}{ Pentobarbital } & \multicolumn{2}{|c|}{ Control } & \multicolumn{2}{|c|}{ Meperidine } \\
\hline & mean & $\mathrm{SE}$ & mean & SE & mean & SE & mean & SE \\
\hline $\mathrm{Pa}_{O_{2}}(\mathrm{~mm} \mathrm{Hg})$ & 447 & 14 & 426 & 12 & 562 & 4 & 562 & 3 \\
\hline $\mathrm{Pa}_{\mathrm{CO}_{2}}(\mathrm{~mm} \mathrm{Hg})$ & 37 & 2 & 36 & 1 & 38 & 1 & 38 & 1 \\
\hline $\mathrm{T}_{\mathrm{A}}\left({ }^{\circ} \mathrm{C}\right)$ & 36.9 & 0.1 & 36.9 & 0.1 & 37.0 & 0.1 & 37.0 & 0.1 \\
\hline $\mathrm{H}_{\exp }(\%)$ & 0.8 & 0 & 0.9 & 0 & 0.9 & 0 & 0.9 & 0 \\
\hline
\end{tabular}

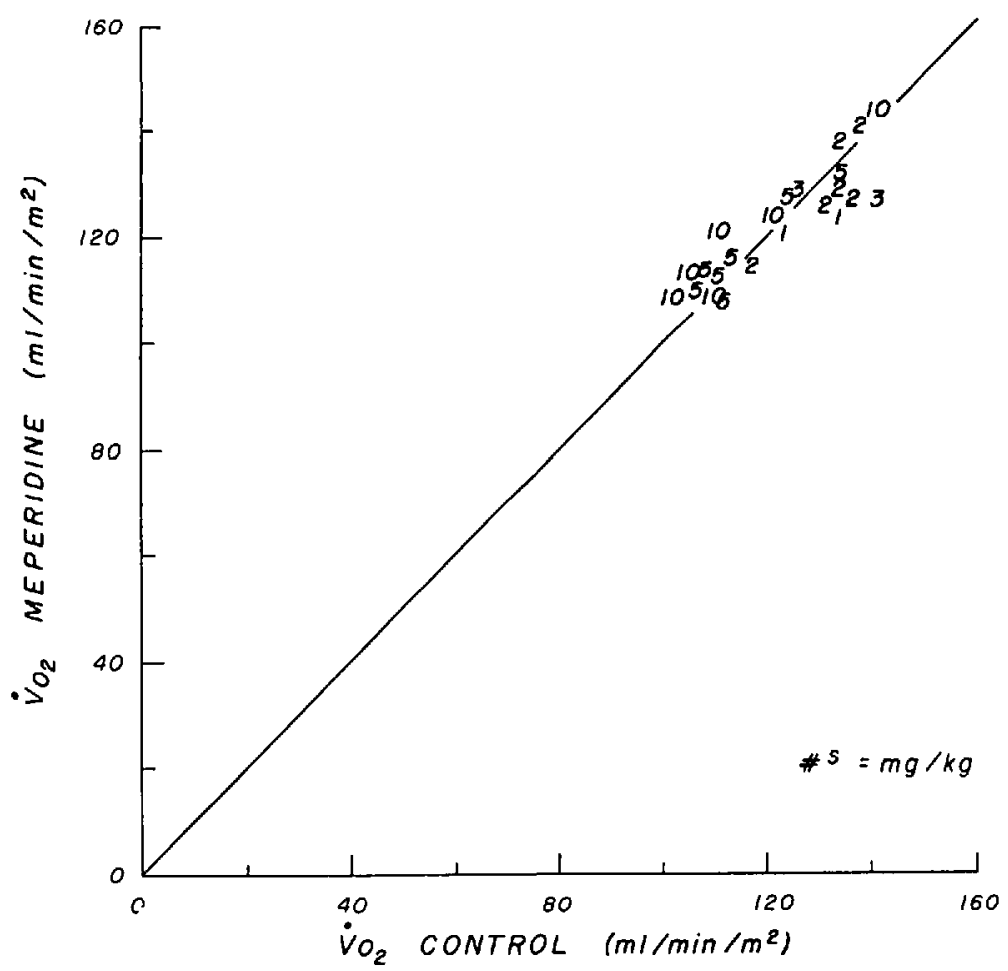

FICURE 2. $\dot{V} \mathrm{o}_{2}$ before and after meperidine in six dogs. Numbers refer to meperidine dose in $\mathrm{mg} / \mathrm{kg}$. Solid diagonal line is line of identity.

Despite these reservations, the following extrapolation is considered a useful exercise. In the dogs of the present and previous studies, ${ }^{11,13}$ average values were as follows: (1) brain weight $80 \mathrm{gm}$; (2) control $\mathrm{CMRo}_{2} 4.6 \mathrm{ml} / \mathrm{min} / 100 \mathrm{gm}$; (3) surface area $0.70 \mathrm{~m}^{2}$; and (4) control $\dot{\mathrm{V}}_{2} 123 \mathrm{ml} / \mathrm{min} / \mathrm{m}^{2}$. Thus, actual $\mathrm{CMRO}_{2}$ and $\dot{\mathrm{VO}}_{2}$ values in millilitres per minute were 3.7 and 86 , respectively, and $\mathrm{CMRO}_{2}$ was 4.3 per cent of $\dot{\mathrm{V}} \mathrm{o}_{2}$. Comparable values in man during halothane anaesthesia, corrected to $37^{\circ} \mathrm{C}$, are $2.94 \mathrm{ml} / \mathrm{min} / 100 \mathrm{gm}$ for $\mathrm{CMRo}_{2}{ }^{19}$ and $140 \mathrm{ml} / \mathrm{min} / \mathrm{m}^{2}$ for $\dot{V}_{o_{2}}{ }^{7}$ Application of these values to an assumed average brain weight of $1400 \mathrm{gm}$ and a body surface area of $1.7 \mathrm{~m}^{2}$ results in a $\mathrm{CMRo}_{2}$ of 


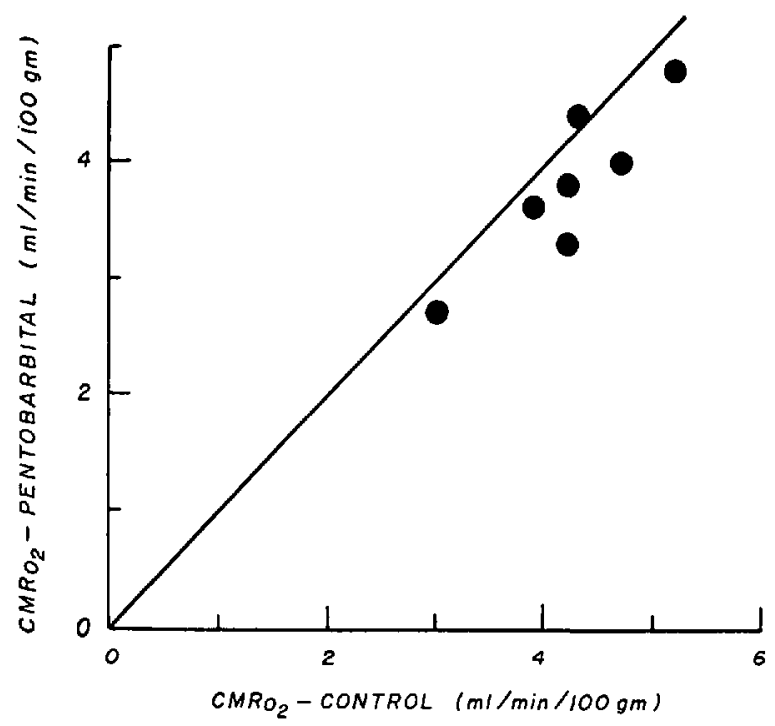

Figure 3. $\mathrm{CMRO}_{2}$ observed before and after pentobarbital $2 \mathrm{mg} / \mathrm{kg}$ in each of seven dogs. Solid diagonal line is line of identity.

$41.2 \mathrm{ml} / \mathrm{min}$, and $\dot{\mathrm{Vo}}_{2}$ of $238 \mathrm{ml} / \mathrm{min}$; thus $\mathrm{CMRo}_{2}$ is 17 per cent of $\dot{\mathrm{V}} \mathrm{o}_{2}$. If it is assumed that pentobarbital and meperidine produce the same percentage changes in $\dot{\mathrm{V}}_{2}$ and $\mathrm{CMRo}_{2}$ in man as observed in the dog, and that these effects are additive, the total decrease of 23 per cent in $\mathrm{CMRO}_{2}$ would amount to a decrease of 4 per cent in total $\mathrm{VO}_{2}$ in man. When this is added to the decrease of 7 per cent in total $\dot{\mathrm{VO}}_{2}$ seen with pentobarbital, a total decrease in $\dot{\mathrm{VO}}_{2}$ of 11 per cent is obtained. This compares favourably with the reduction of 12 per cent in $\dot{V}_{2}$ observed in man at a comparable halothane concentration, ${ }^{7}$ and the reduction in $\dot{\mathrm{VO}}_{2}$ of 11 per cent in unanaesthetized man. ${ }^{6}$ Finally, it should be noted that analysis of the methodologies and relative magnitudes involved indicates that the individual $\mathrm{CMRo}_{2}$ decreases observed with either pentobarbital or meperidine would not be expected to be detected in the total-body $\dot{V}_{O_{2}}$ determinations of the present studies. ${ }^{20}$

The concept of the interrelationship between anaesthetic drugs and cerebral metabolism and function has undergone considerable revision in recent years. To paraphrase Kety, about 20 years ago investigators in the field of brain function and metabolism expected to find good correlation among cerebral oxygen consumption, energy production, and function. ${ }^{21}$ At this time, anaesthesia still was suspected to result primarily from a decreased production of energy which in turn produced a change in cerebral function. The realization that certain mental states (for example, sleep, mental arithmetic) were clearly associated with functional changes, but were without detectable changes in cerebral oxygen consumption, led to the idea that the brain is more like a computer than a pump or motor, and a direct correlation between cerebral oxygen consumption and function would not necessarily be obtained and should not be expected. This view stresses that cerebral metabolism and activity should be viewed as 


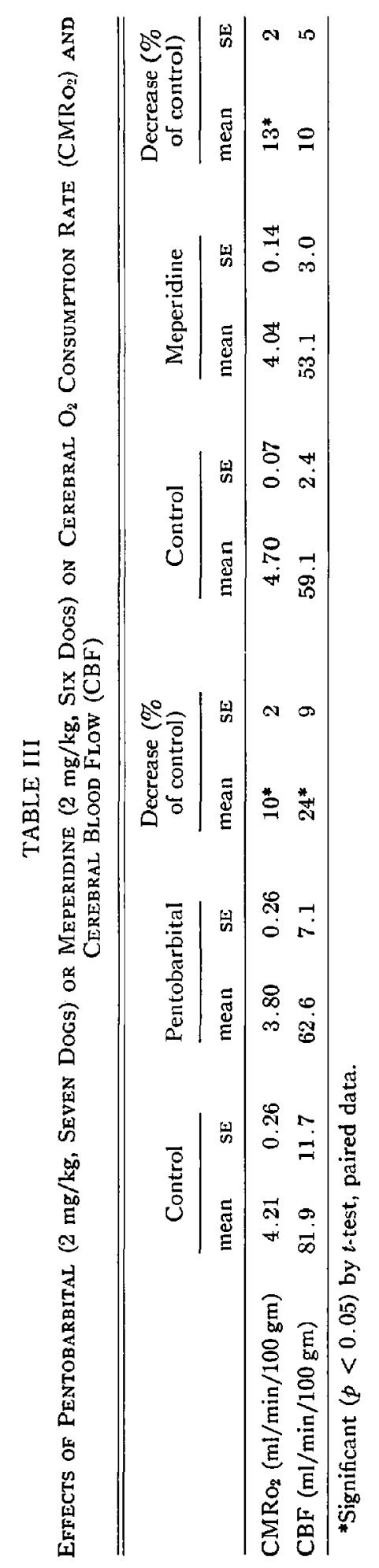


TABLE IV

Pacon, Epidural Temperature (Te), Mean Arterial Pressure

(MAP), SagitTal Sinus $\mathrm{PO}_{2}\left(\mathrm{PSSO}_{2}\right)$, and End-Expired

Halothane Concentration $\left(\mathrm{H}_{\text {exp }}\right)$ in $\mathrm{CMRO}_{2}$ Studies

\begin{tabular}{|c|c|c|c|c|c|c|c|c|}
\hline & \multicolumn{2}{|c|}{ Control } & \multicolumn{2}{|c|}{ Pentobarbital } & \multicolumn{2}{|c|}{ Control } & \multicolumn{2}{|c|}{ Meperidine } \\
\hline & mean & $\overline{\mathrm{SE}}$ & mean & $\mathrm{SE}$ & mean & $\overline{S E}$ & mean & SE \\
\hline $\mathrm{PaCO}_{2}(\mathrm{~mm} \mathrm{Hg})$ & 40 & 0 & 39 & 0 & 39 & 1 & 41 & 2 \\
\hline $\operatorname{Te}\left({ }^{\circ} \mathrm{C}\right)$ & 37.0 & 0 & 37.0 & 0 & 36.9 & 0.1 & 36.9 & 0.1 \\
\hline $\operatorname{MAP}(\mathrm{mm} \mathrm{Hg})$ & 105 & 5 & 103 & 5 & 99 & 4 & 93 & 10 \\
\hline $\mathrm{Pss}_{2}(\mathrm{~mm} \mathrm{Hg})$ & 53 & 6 & 43 & 4 & 40 & 1 & 41 & 2 \\
\hline $\mathrm{H}_{\mathrm{exp}}(\%)$ & 0.8 & 0 & 0.9 & 0 & 0.9 & 0 & 0.9 & 0 \\
\hline
\end{tabular}

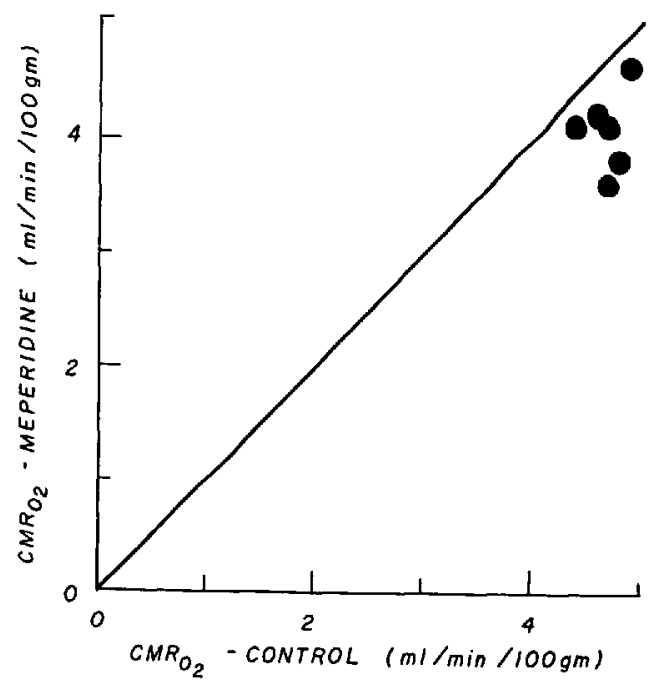

Figure 4. $\mathrm{CMRO}_{2}$ values observed before and after meperidine $2 \mathrm{mg} / \mathrm{kg}$ in each of six dogs. Solid diagonal line is line of identity.

handmaidens, so to speak, rather than metabolism being the precursor of activity. This is compatible with the report of a decrease in $\mathrm{CMRO}_{2}$ with halothane ${ }^{13}$ and an increase in $\mathrm{CMRo}_{2}$ with nitrous oxide, ${ }^{14}$ even though both are anaesthetics. It also necessarily leads to the conclusion that generalizations about the effects of hypnotics, narcotics, and anaesthetics on $\mathrm{CMRo}_{2}$ clearly are not justified at this time.

\section{SUMMARY}

The individual effects of two premedicant drugs, pentobarbital and meperidine, on both total-body oxygen consumption $\left(\dot{V}_{O_{2}}\right)$ and cerebral oxygen consumption $\left(\mathrm{CMRo}_{2}\right)$ rates were studied in dogs during light halothane anaesthesia. $\dot{\mathrm{V}}_{2}$ was measured by means of a modified closed-circuit spirometry apparatus. $\mathrm{CMRo}_{2}$ was calculated from the difference between arterial and sagittal-sinus oxygen content and from the directly measured cerebral blood flow. Pentobarbital 
decreased $\mathrm{V}_{2}$ by 7 per cent and $\mathrm{CMRo}_{2}$ by 10 per cent. Meperidine had no effect on $\dot{\mathrm{V}}_{2}$, but decreased $\mathrm{CMRo}_{2}$ by 13 per cent. These findings are discussed in relation to previous reports of the effects of preanaesthetic medication on $\dot{\mathrm{V}}_{2}$ in man and current concepts of the relationship between cerebral metabolism and function.

\section{RÉSUMÉ}

Au cours d'une anesthésie légère d l'halothane, nous avons étudié les effets individuels de deux médicaments employés en prémédication, le pentobarbital et la mépéridine, effets à la fois sur la $\dot{\mathrm{VO}}_{2}$ et le $\mathrm{CMRo}_{2}$. Nous avons mesuré la $\dot{V}_{2}$ à l'aide d'un appareil modifié de spirométrie en circuit fermé. Le $\mathrm{CMRO}_{2}$ a été calculé d'après la différence entre le contenu en oxygène du sang artériel et du sinus sagittal et la mesure directe du débit sanguin cérébral. Le pentobarbital diminue de 7 pour cent la $\dot{V}_{2}$ et, de 10 pour cent, le $\mathrm{CMRo}_{2}$. La mépéridine n'a pas d'effet sur la $\dot{\mathrm{V}}_{2}$ mais elle diminue de 13 pour cent le $\mathrm{CMRo}_{2}$. Nous discutons ces résultats en songeant à des études antérieures sur les effets de la prémédication anesthésique sur la $\dot{\mathrm{V}}_{2}$ chez l'homme et les théories récentes concernant les rapports entre le métabolisme cérébral et les fonctions cérébrales.

\section{REFERENCES}

1. Guenel, A. E. Metabolism and Reflex Irritability in Anesthesia. J.A.M.A. 83: 1736 (1924).

2. NgaI, S. H. \& PApper, E. M. Metabolic Effects of Anesthesia. Springfield, Illinois: Charles C Thomas (1962). Pp. 89.

3. Orkin, L. R.; Egge, R. K.; \& Rovenstine, E. A. Effect of Nisentil, Meperidine, and Morphine on Respiration in Man. Anesthesiology. 16: 699 (1955).

4. Martinez, L. R.; von Euler, C.; \& Norlander, O. P. Ventilatory Exchange and AcidBase Balance before and after Preoperative Medication. Acta Anaesth. Scandinav. 11: 139 (1967).

5. Smith, T. C.; Stephen, G. W.; Zetger, L.; \& Wollman, H. Effects of Premedicant Drugs on Respiration and Gas Exchange in Man. Anesthesiology. 28: 883 (1967).

6. Theye, R. A. \& Tuory, G. F. Considerations in the Determination of Oxygen Uptake and Ventilatory Performance during Methoxyflurane Anesthesia in Man. Anesth. \& Analg. 43: 306 (1964).

7. Theye, R. A. \& Tuohy, G. F. Oxygen Uptake during Light Halothane Anesthesia in Man. Anesthesiology. 25: 627 (1964).

8. Theye, R. A. \& Messick, J. M., JR. Measurement of Oxygen Consumption by Spirometry during Halothane Anesthesia. Anesthesiology. 29; 361 (1968).

9. Theye, R. A. Blood $\mathrm{O}_{2}$ Content Measurement Using the $\mathrm{O}_{2}$ Electrode. Anesthesiology. 28: $773(1967)$.

10. Michenfelder, J. D.; Messick, J. M., Jr.; \& Theye, R. A. Simultaneous Cerebral Blood Flow Measured by Direct and Indirect Methods. J. Surg. Res. 8: 475 (1968).

11. Michenfelder, J. D. \& Theye, R. A. Hypothermia: Effect on Canine Brain and WholeBody Metabolism. Anesthesiology. 29: 1107 (1968).

12. Alexander, S. C.; Cohen, P. J.; Wollman, H.; Smith, T. C.; Reivich, M.; \& Vanden Molen, R. A. Cerebral Carbohydrate Metabolism during Hypocarbia in Man: Studies during Nitrous Oxide Anesthesia. Anesthesiology. 26: 624 (1965).

13. Thexe, R. A. \& Michenfelder, J. D. The Effect of Halothane on Canine Cerebral Metabolism. Anesthesiology. 29: 1113 (1968).

14. Theye, R. A. \& Michenfecter, J. D. The Effect of Nitrous Oxide on Canine Cerebral Metabolism. Anesthesiology. 29: 1119 (1968).

15. Alrmge, W. N. Action of Barbiturates upon Respiratory Enzymes. In J. L. Mongar \& A. V. S. de Reuch, Enzymes and Drug Action. Boston: Little, Brown (1962), pp. 155-69. 
16. Bunns, J. J. Role of Biotransformation. In E. M. Papper \& R. J. Kitz. Uptake and Distribution of Anesthetic Agents. New York: McGraw-Hill (1963), pp. 177-88.

17. Brodie, B. B.; Burns, J. J.; Mark, L. C.; Lief, P. A.; Bernstein, Eleanore; \& Papper, E. M. The Fate of Pentobarbital in Man and Dog and a Method for Its Estimation in Biological Material. J. Pharmacol. Exper. Therap. 109: 26 (1953).

18. Sokozoff, L. Metabolism of the Central Nervous System in Vivo. In Handbook of Physiology, Section 1: Neurophysiology. Vol. 3, Washington, D.C.; American Physiological Society (1960), pp. 1843-64.

19. Cohen, P. J.; Wolmman, H.; Alexander, S. C.; Chase, P. E.; \& Behan, M. G. Cercbral Carbohydrate Metabolism in Man during Halothane Anesthesia. Anesthesiology. 25: 185 (1964).

20. Messick, J. M., Jr. The Effects of Meperidine and Pentobarbital on Canine Whole Body and Cerebral $\mathrm{O}_{2}$ Consumption Rates. Thesis, Mayo Graduate School of Medicine (University of Minnesota), Rochester, 1968.

21. BunKER, J. P. \& VANDAM, L. D. Effects of Anesthesia on Metabolism and Cellular Functions. Pharmacol. Rev. 17: 183 (1965). 